\title{
Knowing through interspecies relationality in tourism? Animal agency in human-sled dog encounters
}

Mikko Äijälä, University of Lapland, Graduate School \& Multidimensional Tourism Institute (MTI)

A countless number of individual animals representing several species are nowadays involved in the tourism industry. Animals and tourism intersect in many ways, whether as tourist attractions as such, as wildlife conservation tools, as travel companions, or as culinary experiences for tourists (Fennell, 2012; Markwell, 2015). This also applies to the northern parts of Fennoscandia referred to as Arctic Europe within the tourism industry (Visit Arctic Europe, n.d.). For example, Finnish Lapland is a popular tourism destination especially in wintertime and the number of (semi-)domesticated animals working within the tourism industry is great (García-Rosell \& Äijälä, 2018) and the brand value of animals for tourism industry is significant. One of the most popular animal species is the dog, as dog sledding has become one of the most important activities in the ongoing rapid growth of tourism in Arctic Europe (Granås, 2018).

The dog as a companion animal has a special, yet controversial, place in human communities as dogs are seen both as 'man's best friend' with the capability for rational thought, and as objects for human values. Despite - or maybe because of - the extensive shared history of dogs and humans, the dog's place is difficult to define. The social space for dogs is both inside and outside of human society and human understanding of dogs' consciousness and self-fulfillment is very limited (Koski \& Bäcklund, 2017). Given their status associated with polar and adventure histories, sled dogs in particular occupy a liminal position, as in human perceptions, they often reside on the boundary between the domestic and the wild (Granås, 2018; Onion, 2009). Dog sledding is one of the fairly new practices that dogs have occupied, as particularly in Scandinavia people have a rather short history in terms of using dogs as draft animals (Knudsen, 2019) - let alone using them in touristic dog sledding in Arctic Europe.

Tourism is "a relational phenomenon", which "comes about and contributes to shaping our world through relational encounters" (Jóhannesson, Ren, \& van der Duim, 2015, p. 2), in which the roles and characteristics of related agents are co-constituted (e.g. Jóhannesson et al., 2015). Through tourism, sled dogs become part of relational encounters between several agents, including dogs themselves, tourists, entrepreneurs, DMO representatives and travel agents. To 
achieve any success, these encounters require the development of effective communication and cooperation. Practices, such as goal-oriented training of the dogs, requires understanding, empathy and communication also in interspecies level, which entails the idea that the dog is capable of cooperative communication in certain level, and therefore possesses "some kind of agency" (Koski \& Bäcklund, 2017, p. 11). However, dogs' own role and agency in tourism and tourism research is often overlooked (Bertella, 2014).

During the past decade, scholars in social sciences and humanities have started to realize that humans depend on animal lives in several ways. One of the most common approaches has been to study human images of and attitudes towards animals. Another widely used approach has been the ethics of the human use and abuse of animals and the possibility of animal rights (Räsänen \& Syrjämaa, 2017). Animal ethics as an area of inquiry has started to gain ground also in the field of tourism research (Fennell, 2012). These approaches rest on human representation of animals. Problems of representation do not remain isolated, but rather affect the ways in which society interacts with non-humans as it disregards the presence of non-human agency in theory and possibly restrains the agency in practice (Lulka, 2004, p. 446).

Most recently, animal agency has been adopted as the focus in studying human-animal relations in order to understand the agentive role of animal species and individuals in human communities (Räsänen \& Syrjämaa, 2017). This approach focuses on exploring the ways in which non-humans themselves might have subjectivities, agency and practices through which they might create lifeworlds of their own that may have an impact on human ideas of animals themselves (Johnston, 2008). In the field of tourism research, the analysis of status, significance and agency of animals has remained at a rather superficial level apart from some exceptions. Therefore, animals have mostly been considered as resources and passive objects which can be used for human purposes (Bertella, 2014; Yerbury, Boyd, Lloyd, \& Brooks, 2017; see also Äijälä, GarcíaRosell, \& Haanpää, 2016).

Following the patterns of tourism development requires adaptation with reference to practices prevailing around touristic dog sledding. These issues relate to questions about science, capitalist industry, ethics, welfare and politics (Philo \& Wilbert, 2000, p. 2) defining "the meaning, the agency and the subjectivity of both the keeper and the kept" (Buller, 2016, pp. 208-209). However, animals are not passive participants as they shape tourism practices through their actions and reactions and bring their own experiences and life history to the human-animal encounter (Notzke, 2019). Practices such as training sled dogs and providing housing to them in kennels of a certain size situated in a certain location are multispecies affairs. As such, they are about human control as well as about human-animal modifications and modes of co-existence, which derive from, yet also trouble, the relations we humans think we have with sentient yet domesticated, non-humans (Buller, 2016). Through collaborative encounters in touristic dog sledding, the dogs object to their roles and enter into new relations and collaborative arrangements (see Picken, 2018). This indicates that not only humans but also animals are capable of agency (Buller 2012; Philo \& Wilbert, 2000). The ability to act, effect change, or make a difference is multidirectional and does not come from individuals as "purified entities", since "everything is engaged in relations" (Urbanik, 2012, p. 43). 
Given the important role sled dogs play in tourism industry in Arctic Europe, and the fact that they inhabit a controversial space in human perceptions, and that, until recently, tourism researchers have been rather reluctant to work around issues of animal agency, it is important to explore sled dogs as social agents in relation to humans and in their own right. The question of non-human agency entails to be approached from the viewpoint of relationality between non-humans and humans. The point of departure is non-representational theory, which takes the argument that life is based on and in movement (Thrift, 2008; see Ingold, 2011). Movement, as a shared practice between animals and humans (Buller, 2012; Lulka, 2004), enables interspecies, non-verbal communication and cooperation between the agents (Gooch, 2008; Holmberg, 2019). As a result, human-animal encounters in tourism can be constructive. According to Buller (2012, p. 153) "movement and the sharing of movement offer us the potential for original ways of knowing animals and of understanding our relationship to them".

Methodologically, the endeavor of evoking "the fleshy presences and absences of animals in certain spaces, representations and discourses” (Brown \& Banks, 2015, p. 96) requires to move away from human exceptionalism in knowledge production and scientific practice. One can follow the existing collection of ethnographic research and writing known as multispecies ethnography (Kirksey \& Helmreich, 2010; Ogden, Hall, \& Tanita, 2013; see Buller, 2015) - or sometimes as ethnography after humanism (Hamilton \& Taylor, 2017). To explore the diverse interactions between mobile humans - and maybe even more mobile animals - demands to tackle the non-representational dimensions of spatially and temporally complex lifeworlds (Vannini, 2015). Moving image methodologies offer a technique for monitoring, tracking and analysis of the spatialities of animal culture (Hodgetts \& Lorimer, 2015) and a means to explore the non-representational dimensions of the human-animal encounter (Brown \& Banks, 2015; Lorimer, 2010) in order to evoke the presence and agency of sled dogs.

Methodological choices base on the understanding that tourism practices expose both humans and dogs to different forms of encounter and learning, which differ from more everyday human-dog interactions, such as dog walking (e.g. Holmberg, 2019). Practices of human -sled dog encounters with the shifting ecologies, topographies, terrains and proximities require embodied ways of knowing across species and geographical difference. According to Brown and Dilley (2012) that bodily knowing relies on anticipatory ways of knowing-with. Tracing the encounters through relationality reveals routine practice as well as eventful and troubling interruptions to pre-fixed categories in touristic dog sledding, which sheds light on ways of being-, acting- and knowing-with (Brown \& Dilley, 2012; Buller, 2015; see also Haanpää, Salmela, García-Rosell, \& Äijälä, 2019).

Understanding the value of animals only in economic - namely human - terms may have serious consequences when it comes to animals as living beings (see Fennell, 2012) and, consequently, regarding our understanding of tourism practices (Granås, 2018; see Knight, 2010). With regard to animal agency, sentience towards the interactional practices contributes to suggesting what matters, or what might matter, to animals as subjective selves (Buller, 2015). Responsible practice towards - and with - animals is not only about allowing animals to be articulate, but humans to nourish ways of knowing-with that enable acknowledgment of such articulations 
"in a timely and geographically-attuned manner" (Brown \& Dilley, 2012, p. 44). What follows is that collaborative tourism knowledge is not about making the subjects consensual or captive to knowledge production but about allowing them more freedom and space in the collaborative process (Picken, 2018; see Haanpää et al., 2019). Regarding the argument that place-sharing and place-making is generated from a variety of shared and collaborative practices and technologies in human-animal encounters (Buller, 2016), we should be sensitive to the collaborative ways of knowing if we are to support responsible planning and development of tourism.

\section{References}

Bertella, G. (2014). The co-creation of animal-based tourism experience. Tourism Recreation Research, 39, 115-125. https://doi.org/10.1080/02508281.2014.11081330

Brown, K. M., \& Banks, E. (2015). Close encounters: Using mobile video ethnography to understand human-animal relations. In. C. Bates (Ed.), Video methods: Social science research in motion (pp. 95-120). Abingdon, OX: Routledge.

Brown, K., \& Dilley, R. (2012). Ways of knowing for 'response-ability' in more-than-human encounters: The role of anticipatory knowledges in outdoor access with dogs. Area, 44(1), 37-45. https://doi.org/10.1111/j.1475-4762.2011.01059.x

Buller, H. (2012). "One slash of light, then gone": Animals as movement. Etudes Rurales, 189, 139154.

Buller, H. (2015). Animal geographies II: Methods. Progress in Human Geography, 39, 374-384. https://doi.org/10.1177/0309132514527401

Buller, H. (2016). Closing the barn door. In K. Bjørkdahl \& T. Druglitrø (Eds.), Animal housing and human-animal relations: Politics, practices and infrastructures (pp. 199-210). Abingdon, OX: Routledge.

Fennell, D. A. (2012). Tourism and animal ethics. Abingdon, OX: Routledge.

García-Rosell, J.-C., \& Äijälä, M. (2018). Animal-based tourism in Lapland. In J. Ojuva (Ed.), Animal welfare in tourism services: Examples and practical tips for the well-being of animals used for tourism in Lapland (pp. 10-24). Rovaniemi: Lapland University of Applied Sciences.

Gooch, P. (2008). Feet following hooves. In T. Ingold \& J. L. Vergunst (Eds.), Ways of walking: Ethnography and practice offoot (pp. 67-80). Abingdon, OX: Routledge.

Granås, B. (2018). Destinizing Finnmark: Place making through dogsledding. Annals of Tourism Research, 72, 48-57. https://doi.org/10.1016/j.annals.2018.05.005

Haanpää, M., Salmela, T., García-Rosell, J.-C., \& Äijälä, M. (2019). The disruptive 'other'? Exploring human-animal relations in tourism through videography. Tourism Geographies. https://doi. org/10.1080/14616688.2019.1666158

Hamilton, L., \& Taylor, N. (2017). Ethnography after humanism: Power, politics and method in multi-species research. London: Palgrave Macmillan. 
Hodgetts, T. \& Lorimer, J. (2015). Methodologies for animals' geographies: Cultures, communication and genomics. Cultural Geographies, 22, 285-295. https://doi.org/10.1177/1474474014525114

Holmberg, T. (2019). Walking, eating, sleeping: Rhythm analysis of human/dog intimacy. Emotion, Space and Society, 31, 26-31. https://doi.org/10.1016/j.emospa.2019.03.002

Ingold, T. (2011). Being alive: Essays on movement, knowledge and description. Abingdon, OX: Routledge.

Jóhannesson, G. T., Ren, C., \& van der Duim, R. (2015). Tourism encounters, controversies and ontologies. In G. T. Jóhannesson, C. Ren, \& R. van der Duim (Eds.), Tourism encounters and controversies: Ontological politics of tourism development (pp. 1- 19). Farnham, SY: Ashgate.

Johnston, K. (2008). Beyond the clearing: towards a dwelt animal geography. Progress in Human Geography, 32, 633-649. https://doi.org/10.1177/0309132508089825

Kirksey, E. \& Helmreich, S. (2010). The emergence of multispecies ethnography. Cultural Anthropology, 25, 545-576. https://doi.org/10.1111/j.1548-1360.2010.01069.x

Knight, J. (2010). The ready-to-view wild monkey: The convenience principle in Japanese wildlife tourism. Annals of Tourism Research, 37, 744-762. https://doi.org/doi:10.1016/j.annals.2010.01.003

Knudsen, I. B. (2019). From polar exploration to sled dog racing: A brief overview of some important elements in Norwegian sled dog history. In R. Waaler \& K. Skjesol (Eds.), Dog sledding in in Norway: Multidisciplinary research perspectives (pp. 15-44). Zürich: Lit Verlag.

Koski, L., \& Bäcklund, P. (2017). Whose agency? Humans and dogs in training. In T. Räsänen \& T. Syrjämaa (Eds.), Shared lives of humans and animals: Animal agency in the global North (pp. 11-23). Abingdon, OX: Routledge.

Lorimer, J. (2010). Moving image methodologies for more-than-human geographies. Cultural Geographies, 17, 237-258. https://doi.org/10.1177/1474474010363853

Lulka, D. (2004). Stabilizing the herd: Fixing the identity of nonhumans. Environment and Planning D: Society and Space, 22, 439-463. https://doi.org/10.1068/d298

Markwell, K. (Ed.) (2015). Animals and tourism: Understanding diverse relationships. Bristol: Channel View Publications.

Notzke, C. (2019). Equestrian tourism: Animal agency observed. Current Issues in Tourism, 22, 948966. https://doi.org/10.1080/13683500.2017.1349081

Ogden, L. A., Hall, B., \& Tanita, K. (2013). Animals, plants, people, and things. A review of multispecies ethnography. Environment and Society: Advances in Research, 4, 5-24. https://doi. org/10.3167/ares.2013.040102

Onion, R. (2009). Sled dogs of the American North: On masculinity, whiteness and human freedom. In S. E. McFarland \& R. Hediger (Eds.), Animals and agency: An interdisciplinary exploration (pp. 129-155). Leiden: Brill.

Philo, C., \& Wilbert, C. (2000). Animal spaces, beastly places: An introduction. In C. Philo \& C. Wilbert (Eds.), Animal spaces, beastly places: New geographies of human-animal relations (pp. 1-35). London: Routledge. 
Picken, F. (2018). Knowing the aquatic other: Unleashing blackfish. In C. Ren, G. T. Jóhannesson, \& R. van der Duim (Eds.), Co-creating tourism research: Towards collaborative ways of knowing (pp. 147-161). Abingdon, OX: Routledge.

Räsänen, T., \& Syrjämaa, T. (2017). Introduction. In T. Räsänen \& T. Syrjämaa (Eds.), Shared lives of humans and animals: Animal agency in the global North (pp. 1-7). Abingdon, OX: Routledge.

Thrift, N. (2008). Non-representational theory: Space, politics, affect. Abingdon, OX: Routledge.

Urbanik, J. (2012). Placing animals: An introduction to the geography of human-animal relations. Lanham: Rowman \& Littlefield Publishers.

Vannini, P. (2015). Non-representational ethnography: New ways of animating lifeworlds. Cultural Geographies, 22, 317-327. https://doi.org/10.1177/1474474014555657

Visit Arctic Europe (n.d.). Retrieved November 19, 2019, from https://visitarcticeurope.com

Yerbury, R., Boyd, W., Lloyd, D., \& Brooks, A. (2017). Right to leisure? Refocusing on the dolphin. Annals of Leisure Research, 20, 368-385. https://doi.org/10.1080/11745398.2017.1314190

Äijälä, M., García-Rosell, J.-C., \& Haanpää, M. (2016). Literature review: Animals as part of tourism. Matkailututkimus, 12(2), 45-59. 